\title{
How inheritance and magmatism influence rifted margins? A case study of the Campos Basin (Brazil)
}

Natasha Stanton (State University of Rio de Janeiro, Brazil); Nick Kusznir (University of Liverpool, UK); Andres Gordon (ACGEO Consulting, Brazil); Renata Schmitt (Federal University of Rio de Janeiro, Brazil)

Copyright 2019, SBGf - Sociedade Brasileira de Geofísica

This paper was prepared for presentation during the $16^{\text {th }}$ International Congress of the Brazilian Geophysical Society held in Rio de Janeiro, Brazil, 19-22 August 2019.

Contents of this paper were reviewed by the Technical Committee of the $16^{\text {th }}$ International Congress of the Brazilian Geophysical Society and do not necessarily represent any position of the SBGf, its officers or members. Electronic reproduction o storage of any part of this paper for commercial purposes without the written consent of the Brazilian Geophysical Society is prohibited.

\section{Abstract}

This study presents new geophysical results to shed light on Campos Basin evolution from early rifting to breakup. Based on aeromagnetic, seismic and gravity inversion we investigate the ocean-continent transition structure, magmatism and the pre-rift configuration. The aim is to constrain the margin architecture and to explore the role of Precambrian basement inheritance and magmatism. We document the lateral variation of crustal rheology, necking geometry and rift segmentation, revealing spatial heterogeneities that show three distinct sectors along the Campos Basin: south, central and north. Depthdependent extension mechanism led to large-scale block rotations and accommodation space in the central and southern Campos Basin, where the deformation was distributed, leading to a gradual thinning. In the northern Campos Basin, a more resistant crust led to abrupt thinning and absence of magmatism. We propose that the CRM evolved from a complex pre-rift inherited lithosphere rheology, which dominated the first stages of rift evolution and played a critical role in determining margin architecture, necking geometry, rift propagation, syn-rift accommodation space and, possibly, magmatism

\section{Introduction}

Rifted margins are the final product of several processes acting during successive phases of deformation. Mapping, sampling and modeling the structures and stratigraphic sequences provide insights into those processes and are crucial to our understanding of their formation and evolution. Continental accretion produces a complex lithospheric architecture, with diverse compositional domains, which have different rheological and mechanical behaviors. The present architecture observed at rifted margins reflects directly the interaction between this pre-existing multilayered canvas (the old lithosphere) and the sequential evolution of deformation in space and time.

The Campos Basin on the southeastern Brazilian margin (Fig. 1) developed over Precambrian-Early Paleozoic terranes, well constrained onshore, known as the Ribeira/ Araçuai belts and the Cabo Frio Tectonic Domain
(CFTD), which has contrasting characteristics when compared to the Oriental Terrane (Stanton et al., 2019).

The onset of rifting at Early Cretaceous was accompanied by extrusive and intrusive magmatism, recorded as tholeiitic dyke swarm onshore (Deckart et al. 1998; Guedes et al., 2005; Valente et al. 2007) and basalt flood, intrusives and alkaline volcanism offshore from Early to Late Cretaceous (Misuzaki et al. 1988; Fodor et al. 1985; Oreiro et al., 2008), characterizing a recurrent magmatism pre-, syn- and post rift phase.

We present new geophysical data that highlights the crustal structure, segmentation and magmatism of the Campos rifted margin. Our results reveal differences from south to north in OCT structure and volcanism which are related to changes in breakup deformation, lithospheric inheritance and regional plate kinematics

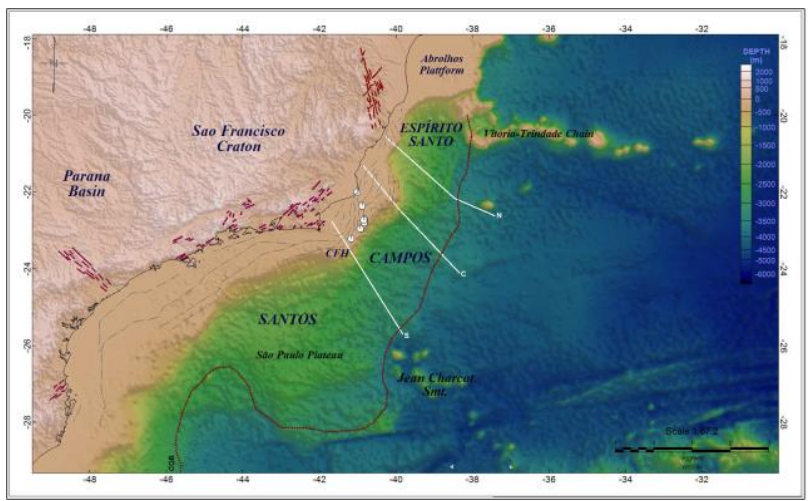

Figure 1- Simplified tectonic map of Southeastern Brazilian margin. CFH- Cabo Frio High. Dike swarms are represented by red lines; white lines show the location of seismic section in Fig. 3. Continent-Ocean Boundary (COB) location from Zalán et al. (2011).

Magnetic and gravity anomaly analysis: calibrating the seismic interpretation

The magnetic data used in this work comprises eight different aerosurveys from the Agência Nacional de Petróleo (ANP) public domain database. In order to enhance lateral contrasts and separate shallow from deep sources, we have applied various transformations (for transformed maps, see Stanton et al., 2019).

To illustrate the crustal architecture we selected three key regional seismic sections (northern, central and southern transects, Fig. 4). Regional crustal basement thickness has been determined using 3D gravity inversion which is carried out in the spectral domain and incorporates a 
lithosphere thermal gravity anomaly correction. The gravity inversion technique used is described in detail in Chappell and Kusznir (2008) and Alvey et al. (2008). Maps of crustal basement thickness derived from gravity inversion, using public domain input data, are shown in Fig. 3. Crustal basement thickness and Moho depth shown on the cross-sections in Fig. 4 for are derived from gravity inversion using sediment thicknesses from seismic reflection data provided by ANP.

\section{Results}

Along the Campos margin, the integration of geophysical data shows a first-order variation in magmatism, crustal thickness and architecture from south to north (Stanton et al., 2019) (Fig. 2). The magnetic anomaly map exhibits dominant NE-SW trends, which are systematically shifted by NW-SE negative zones. This pattern of discontinuity on the NE main structural trends are also observed onshore, represented by transfer faults and discrete ENE fault zones, which dissect Mesozoic dikes.

The basin architecture is characterized by different tectonic domains from continent to ocean: the proximal and necking domains (Fig. 4) display variations in width along strike in magnetic anomalies. These are associated with variations in syn-rift magmatic rocks abundance, especially at the Southern and Central segments. The crust is bipartite, displaying an upper massive crust above a highly reflective and layered middle/lower crust. The Northern Campos segment exhibits a massive crystalline basement at the Proximal and Necking zones, with deep shear zones.

At northern Campos, no first-order magnetic anomalies or magmatic rocks are observed. While along the highly extended domain (HED) there is evidence of magmatism in northern Campos based on the magnetic pattern. This contrasts with Central and Southern Campos, where the magnetic anomalies suggest absence of magmatic rocks at the distal margin and the COB.

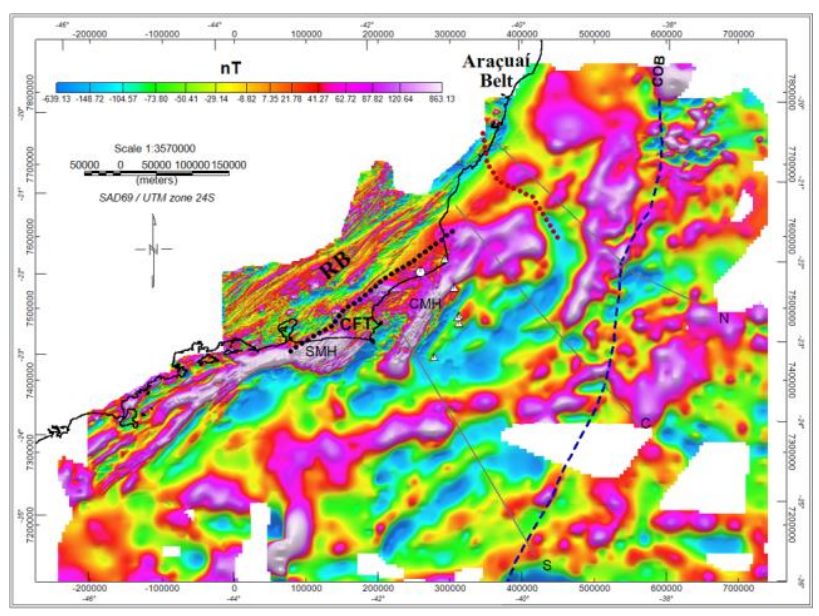

Figure 2- Total magnetic anomaly map. CMH, SMH - Campos and Santos Magnetic High, respectively; grey lines - seismic cross sections location; dotted lines: white - the South East
Magnetic Anomaly (SEMA), black - NW-SE discontinuity (modified from Stanton et al., 2019).

Fig. 3 shows that in general, crustal basement thickness from gravity inversion approaches $30 \mathrm{~km}$ or more at the coast, which then reduces distally towards the deep ocean in the east. Predicted crustal thicknesses within the oceanic domain range from 5 to $15 \mathrm{~km}$. These larger values may correspond to anomalously thick oceanic crust. Within the OCT regions, the width of the transition from proximal thick to distal thin crust decreases northwards.

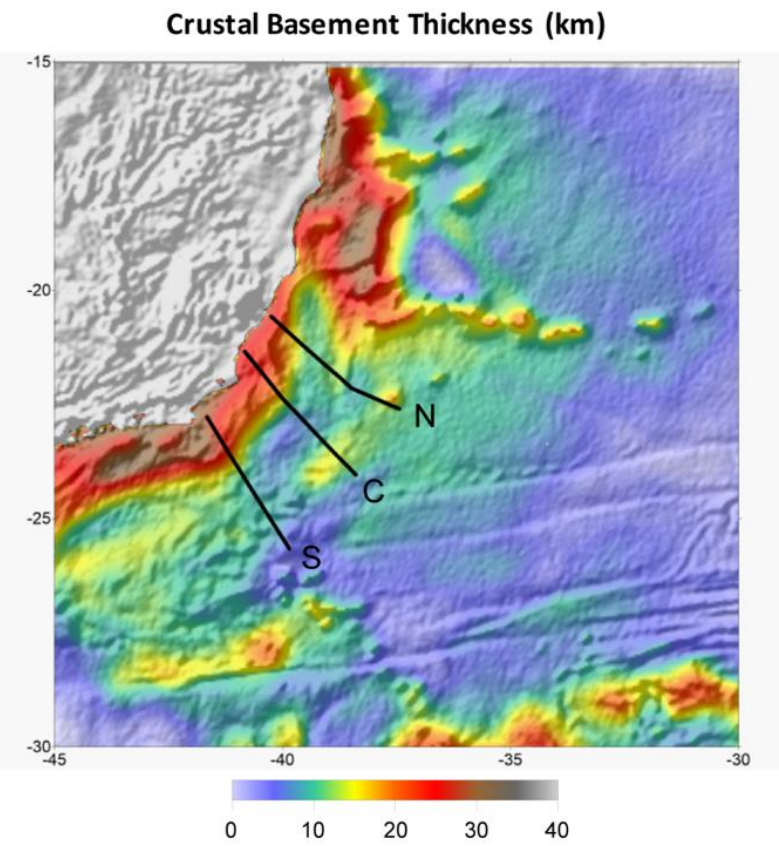

Figure 3- Crustal basement thickness derived from gravity inversion. Black lines show the location of profiles ( $N, C$ and S).

\section{Discussion}

The role of basement inheritance on Campos Basin architecture

The Campos Basin is characterized by contrasting architectural styles from south to north, which correlates with changes in crustal composition, age, structure and magmatic activity.

Based on seismic, gravity and magnetic results we propose that: 1) the northern Campos Basin basement could correspond to the Aracuaí belt; and 2) the CFTD seems to correspond to the central and southern segments basement.

The deformation style is contrastingly different from south to north: On the northern Campos margin, the crust and mantle deformation couple at the NZ and are accommodated by upper crust faults and shear zones near the base of the crust. On the central and southern Campos margins, the extension is accommodated by widely distributed middle and lower crust ductile 
structures. Large-scale grabens seem to be controlled by a SE dipping decollement at the brittle-ductile transition, suggesting a depth-dependent extension.

We have identified three main Architectural margin types at Campos Basin (Stanton et al., 2019) (Fig. 4):

- Type 1 (northern Campos) is characterized by an abrupt architecture, with a narrow and steep crustal necking zone. The HED is wide and devoid of magmatism

- Type 2 (central Campos) is characterized by a layered crust, a relative high ratio of ductile versus brittle crustal layers, resulting in a wide crustal necking zone, a regional decollement and deep ductile shear zones, with isolated magmatism along the margin

- $\quad$ Type 3 (southern Campos) displays a multi-layered crust and gradual NZ highly affected by magmatism preventing normal basin subsidence during early rifting. The HED is devoid of magmatism.

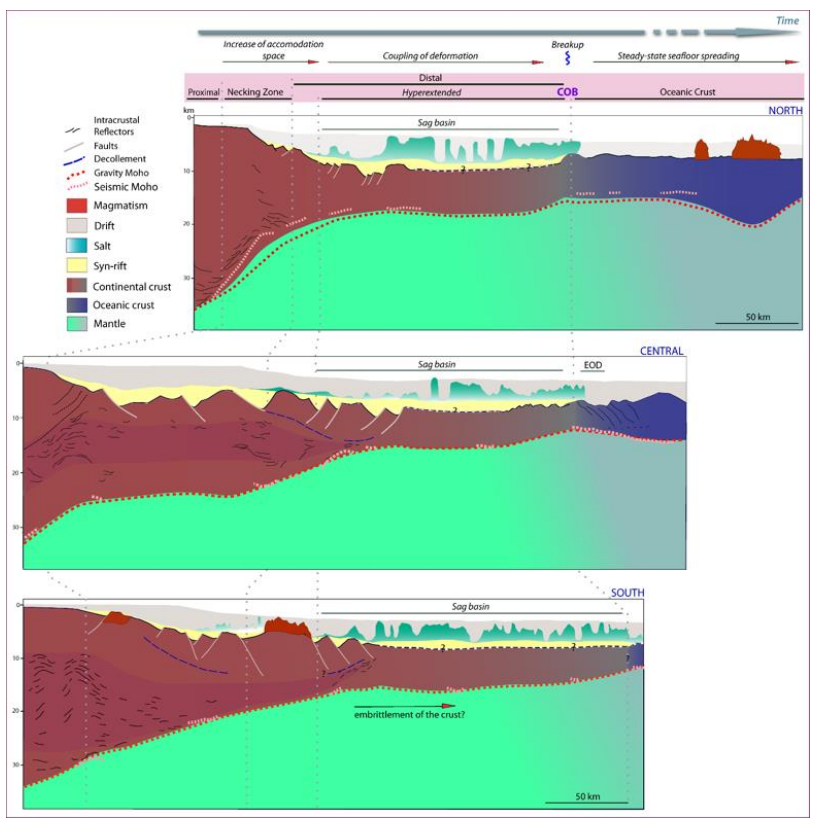

Figure 4- Geological cross-sections of the Campos Basin based on seismic reflection and gravity inversion showing margin architecture variation (After Stanton et al., 2019)

\section{Conclusions}

The inter-relation between basement inheritance, magmatism and rift evolution on Campos Rifted Margin resulted on the present day margin architecture, which shows first-order variations from South to north.

We propose that CRM deformation was dominated by the pre-existing basement inheritance in the early stages. Nevertheless, the Distal Highly-extended Domain (HED) forms a uniformly wide region along the CRM, with the breakup only being achieved after intense crustal extension.

Based on our observations, we believe that the optimal conditions for sedimentary basin formation on rifted margins are associated with an inherited basement characterized by pre-existing structures, a layered crust with a high ductile versus brittle ratio and thus widely distributed deformation and low syn-rift magmatism. (normal geotherm favoring the syn-rift subsidence).

\section{Acknowledgments}

The authors are grateful to CAPES "Science Without Borders" Program for Natasha Stanton Young Talent Grant. This paper is a contribution to IGCP-628 "The geological map and tectonic evolution of Gondwana". R. Schmitt acknowledges the CNPq Grant 309216/2015-0.

\section{References}

Alvey, A., Gaina, C., Kusznir, N.J., Torsvik, T.H., 2008. Integrated crustal thickness mapping and plate reconstructions for the high Arctic, Earth planet. Sci. Lett. 274, 310-321. https://doi.org/10.1016/i.epsl.2008.07.036.

Chappell, A.R., Kusznir, N.J., 2008. Three-dimensional gravity inversion for Moho depth at rifted continental margins incorporating a lithosphere thermal gravity anomaly correction. Geophys. J. Int. 174, 1-13. https://doi.org/10.1111/i.1365-246X.2008. 03803.

Deckart, K., Feraud, G., Marques, L.S., Bertrand, H., 1998. New time constraints on dyke swarms related to the Parana \& Etendeka magmatic province, and subsequent South Atlantic opening, southeastern Brazil. J. Volcanol. Geoth. Res. 80, 67-83. https://doi. org/10.1016/S03770273(97)00038-3.

Fodor, R.V., Vetter, S.K., 1984. Rift-zone magmatism: petrology of basaltic rocks transitional from CFB to MORB, southeastern Brazil margin. Contrib. Mineral. Petrol. 88 307,984. https://doi.org/10.1007/BF00376755.

Guedes, E., Heilbron, M., Vasconcelos, P.M., Valeriano, C.M., Almeida, J.C.H., Teixeira, W., Thomaz Filho, A., 2005. $\mathrm{K} / \mathrm{Ar}$ and $40 \mathrm{Ar} / 39 \mathrm{Ar}$ ages of dykes emplaced in the onshore basement of the Santos Basin, Resende area, SE Brazil: implications for the south Atlantic opening and Tertiary reactivation. J. S. Am. Earth Sci. 18 371-182. https://doi.org/.10.1016/j.jsames.2004.11.008.

Mizusaki, A.M.P., Thomaz-Filho, A., Valença, J., 1988. volcano-sedimentar sequence of neocomiam age in Campos basin (Brazil). Rev. Bras. Geociencias 18 (3), 247-251.

Oreiro, S.G., Cupertino, J.A., Szatmari, P., Thomaz Filho, A., 2008. Influence of pre-salt alignments in post-Aptian magmatism in the Cabo Frio High and its surrounding, Santos and Campos basins, SE Brazil: an example of non-plume related magmatism. J. S. Am. Earth Sci. 25, 116-131. https://doi.org/10.1016/j.jsames.2007.08.006. 
Stanton, N.; Kusznir, N.; Gordon, A.; Schmitt, R. 2019.

Architecture and Tectono-magmatic evolution of the Campos Rifted Margin: Control of OCT structure by basement inheritance. Marine and Petroleum Geology, Volume 100, 43-59.

Stanton, N., Schmitt, R., 2015. Onshore-offshore prolongation of structures between Campos and Santos Basins from aeromagnetic data. In: The 14th International Congress of the Brazilian Geophysical Society. Exp. Abs.

Valente, S.C., Corval, A., Duarte, B.P., Ellam, R.M., Fallick, A.E., Meighan, I.G., Dutra, T., 2007. Tectonic boundaries, crustal weakness zones and plumesubcontinental lithospheric mantle interactions in the Serra do Mar dyke swarm, SE Brazil. Rev. Bras. Geociencias 3, 194-201.

Zalán, P.V., Severino, M., C.G., Rigoti, C.A., Magnavita, L.P., Oliveira, J.A.B., Vianna, A.R., 2011. An entirely new 3D-view of the crustal and mantle structure of a South Atlantic passive margin: Santos, Campos and Espírito Santo Basins, Brazil. In: AAPG Annual Convention and Exhibition. 